\title{
Research on the Reform of Digital Economy Professional Training Mode from the Perspective of "Internet Plus Curriculum Thinking"
}

\author{
Zhian Ren ${ }^{1}$, Lingling Shen ${ }^{1}$, Zejiong Zhou ${ }^{1, *}$ \\ ${ }^{1}$ School of Economics, Anhui University of Finance and Economics, Bengbu, Anhui, China \\ *aczzj123456@163.com
}

\begin{abstract}
Innovative talent training mode is a key problem to be solved in the talent training of digital economy specialty in Colleges and universities. From the new teaching mode of "Internet plus curriculum thinking politics", the training mode of digital economy professionals needs to be improved. Therefore, based on the analysis of the role of "Internet plus curriculum thinking" in the training of digital economy professionals, this paper fully combines the problems and deficiencies of the current digital economy professional training, and proposes that from the top level design to the teaching staff, then to the improvement of the evaluation system and other measures to achieve the goal of cultivating comprehensive digital economy talents with both professional knowledge and ideological and moral quality.
\end{abstract}

Keywords: "Internet plus curriculum thinking politics", Major in digital economy, Talent training mode.

\section{Introduction}

At present, we are in a new era of digitization of information and business activities. New business forms and models of digital economy emerge one after another, which has promoted industrial upgrading and infrastructure optimization. To seize the commanding height of future development and promote the construction of a new development pattern, the key is to give full play to the engine role of digital economy. Under the background of the rising status of digital economy in the national economy, digital economy specialty came into being, and its talents play an important role in promoting digital transformation and upgrading. At present, many colleges and universities in China have opened digital economy majors, such as Shanghai University of Finance and economics, Jilin University, Yunnan University, Nanjing University, Lanzhou University of Finance and economics, Hebei University, Shanghai Normal University, Huazhong University of science and technology, Guizhou University, Harbin University of Commerce, Anhui University of Finance and economics, South China University of technology, etc. Compared with other economic majors, the main feature of the cultivation of talents majoring in digital economy is that they rely more on Internet information technology. At the same time, like other economic majors, this major attaches great importance to the educational role of "curriculum thinking and politics". In the context of "Internet plus", combining the educational function of "curriculum thinking and politics" and the comprehensive use of the new mode of "Internet plus curriculum thinking and politics" to train professionals in digital economy, it has very important practical significance and time value.

\section{The Role and Significance of "Internet Plus Curriculum Thinking and Politics" in the Training of Digital Economy Professionals}

"Internet plus curriculum thinking politics" is a new talent training mode after the eighteen big development. In short, the Internet plus curriculum thinking is a new paradigm to solve the fundamental problem of "cultivating what people, how to train people and nurturing people" in universities, integrating Internet technology into the curriculum teaching, thereby enhancing the ideological education effect of professional courses, and making the "Ideological and political" role of professional courses more obvious (Liu Shuhui, 2017) [1]. Compared with traditional classroom teaching, the "Internet plus curriculum thinking and political education" mode has new characteristics in the following aspects: (1) the pluralism of educational subjects. The main body of traditional education is usually the substitute teacher of the subject. The development of the Internet provides technical support for the development of the classroom. Anyone who can bring students good subject education and ideological and political education can become the main body of education. (2) Diversification of educational carriers. In the past, teachers could only teach through "a pencil and a blackboard", but now they are more "double teaching" online and offline. Students can complete learning tasks online through Xuetong, Chaoxing Erya, Wechat, etc., and even conduct evaluation and examination online. (3) The educational field is spatiotemporal. Students' Ideological and political education activities are often carried out in memorial halls and museums, but people's demands and the internal needs of the whole society are often reflected in daily life. Life experience and growth experience are hidden courses of Ideological and political education. The highly abstract content has a concrete explanation, and the educated can better accept it. "Internet plus ideological and political education" is not only conducive to the cultivation of comprehensive talents with strong professional knowledge and high ideological quality, but also conducive to breaking the drawbacks of the past teaching mode and promoting the further improvement of our education system.

"Internet plus curriculum thinking and politics" plays an important role in the training of digital economy professionals. (1) Digital economy major is different from other economic 
majors. The courses of digital economy major are mainly composed of computer science, economics, data science and statistics. It has high requirements for the utilization of computer and the mastery of information. The development and application of "Internet plus" technology provide more frontiers of data and more advanced and reliable learning methods for the learning of digital economy professionals, and is conducive to stimulating students' innovative spirit and comprehensive ability. (2) Like other economic majors, "Ideological and Political Courses" are very important and can play an educational effect. When learning basic courses, students can not only master economic theory knowledge and improve their professional skills, but also integrate "Ideological and political" into teaching activities such as knowledge module and teaching evaluation; We can also get ideological guidance, help form correct three outlooks and have higher ideological and moral character. Therefore, the use of the Internet plus curriculum thinking and administration mode in the training of digital economy professionals is conducive to breaking through the previous single teaching mode, stimulating students' enthusiasm for learning and improving the efficiency of class teaching. It also helps students to strengthen their faith and enhance their sense of honor. It can promote the continuous improvement of the teaching quality of digital economy specialty, and finally realize the fundamental task of building morality, cultivating people, casting soul and educating people.

\section{The Analysis of the Current Situation of Digital Economy Professionals Training Based on "Internet Plus Curriculum Thinking Politics"}

Although China's digital economy specialty has developed rapidly in recent years, many colleges and universities have successively set up digital economy specialty. Colleges and universities have also made unremitting efforts and continuous exploration on the talent training of digital economy specialty, and achieved certain results. However, if we use the Internet plus curriculum to reflect on the development and construction of China's digital economy, it is easy to find that there are still many problems in the training of digital economy professionals in China.

\subsection{Internet Plus "Level of Application" and "Insufficient"}

At present, many colleges and universities such as Renmin University of China, Nankai University, Beijing Normal University, Nanjing University and Anhui University of Finance and Economics have carried out digital economy. The new teaching mode of "Internet plus teaching" has also promulgated relevant policies and regulations, which requires that the network teaching platform be actively constructed in schools, and the online learning channel for professional courses should be opened for students. But even so, the degree of "Internet plus" in the teaching of digital economy has not met the requirements. (1) Most teachers prefer the traditional teaching method of "blackboard + teacher classroom on-site demonstration". For the courses required by the school, the use of network technology only stays on the surface. For example, courseware upload, class assignment release and release check-in are only carried out on the platform. For students majoring in digital economy, the difficult points in teaching can not be demonstrated with the help of multimedia. They are all dictated by the teacher, and students can not fully master professional knowledge. (2) The speed of "Internet plus" development is not consistent with the pace of information technology training for teachers. Teachers majoring in digital economy are skilled in using computers for information search and command execution, but they are like novices for teaching on the online platform. The platform system is updated quickly, and there are few activities in the application of training, learning and teaching platform organized by institutions in the school. Teachers often can't be handy in the process of use, and even delay the original teaching plan.

\subsection{The Educational Function of "Curriculum Ideological and Political Education" Is Not Brought into Full Play}

Under the new teaching mode, we should promote the construction of "curriculum thinking and politics" into the whole process of teaching and build a pattern of all-round education. From the perspective of digital economy courses, the educational function of "curriculum thought and politics" has not been brought into full play. Some teachers have high professional quality, but their Marxist theoretical literacy is not high. They believe that economic theoretical knowledge is far from ideology and ideological and political aspects, so they can not find the entry point and way of combining digital economy professional knowledge with "Ideological and political elements". Often just to complete the teaching task, they deal with the requirements of the school's documents. Or copy mechanically and deliberately look for a "Ideological and political element", which makes it difficult to integrate with the digital economy curriculum. Or simply talk about "Ideological and political" knowledge during class, and then continue to take professional courses. Such "Ideological and political" only floats on the surface, and students just listen to it. It can not help students establish a correct value understanding of the things around them. In general, simple language stimulation and indoctrination can not establish the potential cognitive basis of Ideological and political knowledge and build positive emotional attitude and value experience for students (Liu Fangxin, 2019) [2].

\section{3. "Internet Plus Curriculum Thinking Politics" Is Not Very High}

Although many colleges and universities are aware of the importance of Internet technology to teaching and take relevant measures to introduce relevant technology, due to the late start time, they have not yet achieved the perfect integration of information technology and ideological and political courses. During the epidemic period, Nankai University carried out online teaching courses of digital economy specialty in many different ways, such as Nailing, Tencent conference, Zoom, Micro class and SPOC (MOOC). For teachers who have just come into contact with these internet teaching platforms, it is not easy to operate smoothly and teach good courses for students. In their spare time, they need to receive further training and do a good job in the recycling and correction of online homework. For these teachers, they don't have much time to find the breakthrough point of the combination of digital economy courses and "Ideological and political" elements. Even if they find it, they don't have time to use network information technology to query materials for further demonstration. In this case, the 
way for students majoring in digital economy to obtain ideological and political education is only limited to ideological and political courses. "Internet plus curriculum thinking politics" is not high enough to be able to improve the timeliness and quality of teaching by using the advantages of Internet technology.

\subsection{A Complete Talent Training Program System Has Not Been Formed}

The existing colleges and universities that offer digital economy major put too much emphasis on the nature and function of digital economy major in their training system. Most of the courses from talent training programs to various levels are aimed at imparting the basic theoretical knowledge of digital economy major and the operation ability of network technology. The value guidance to students is rarely taken as the teaching goal, and the function of curriculum ideological and political education is ignored (Yu Cheng et al., 2020) [3]. In the era of Internet, the imperfection of talent training system will have a negative impact on students' values. Students majoring in digital economy spend more time on the Internet, but they only use mobile phones and computers to find shortcuts for their study, and only require to pass the exam smoothly. What's more, they will be attacked by foreign thought-form due to their addiction to the Internet. After several years of school study, ideological consciousness has not improved significantly. It is difficult to cultivate comprehensive talents with all-round development of morality, intelligence, physique, beauty and labor.

\section{Reform of Digital Economy Professional Training Mode under the Perspective of "Internet Plus Curriculum Thinking"}

In the Internet era, the number of digital economy professionals in the market is in short supply. In order to further meet the needs of development, we must reform the curriculum of digital economy specialty, and keep pace with technological progress and social development.

\subsection{Do A Good Job in the Top-level Design of Talent Training Plan for Digital Economy Specialty}

Training and adapting to the global digital economy professionals, and grasping the construction of "Internet plus curriculum thinking and politics". In order to fundamentally solve the problem that professional courses and ideological and political courses lack the same direction, we must start from the top-level design and overall planning of the curriculum system of digital economy (Chen Weizhi, 2021) [4]. Schools should uphold modern educational concepts and new ideas, clearly understand the key points of teaching in Digital Economics, and actively introduce relevant documents of the new mode of "Internet plus curriculum thinking and administration". According to the actual situation of the University, carefully revise the talent training scheme for digital economy specialty, integrate Internet technology into the syllabus, and combine theory and practice in teaching; The personnel department should implement the new teacher performance evaluation scheme. Other departments shall also do their own work according to the requirements of the documents. From the top-level design, implement the requirements of synchronously improving students' professional quality and ideological and political quality as the primary goal of curriculum teaching.

\subsection{Focuses on Training "Internet Plus Curriculum" Teachers}

To further improve the ability of students majoring in digital economy, we must have a qualified team of teachers. (1) Continuously improve the professional knowledge ability level and information teaching ability of teachers majoring in digital economy. Constantly optimize the teaching mode in the teaching environment where various learning terminals, smart campuses, online learning platforms and other information-based means are used together. Teachers should make full use of the convenience brought by information technology to provide students with more high-quality resources. Continuously improve the teaching quality of digital economy so that students can learn better knowledge and skills. (2) Teachers majoring in digital economy should adhere to the correct political direction and abide by rules and regulations. To establish the awareness of lifelong learning, we should actively and continuously improve our ideological and political education literacy. Fully tap the ideological and political education elements contained in the curriculum and even each chapter, and take the ideological and political curriculum as an indispensable part of daily teaching. Actively introduce family and country feelings, education and exemplary deeds in society, convey correct values to students, and realize the effect of education and education. (3) Colleges and universities should strengthen the training of teachers, actively carry out and send teachers to participate in learning, training and seminars to improve information technology and ideological and political literacy, and fully learn from the valuable experience of other colleges and universities. Improve teachers' teaching level and knowledge structure to provide guarantee for students' development.

\subsection{Optimize the Performance Evaluation System of Digital Economy Specialty}

Performance evaluation is an important part of teaching work. In the past, performance evaluation can not fully reflect the shortcomings of teachers in teaching by assessing the examination results of students in each class. In order to promote the reform of talent training mode of digital economy specialty, we should optimize the performance evaluation system of digital economy Specialty: (1) Extend the evaluation dimension of digital economy specialty curriculum on the basis of the original curriculum evaluation system. From a single professional dimension, it extends to multiple dimensions such as humanistic quality, professional competence and social responsibility (Zhuo Hongming et al., 2019) [5]. "Internet plus curriculum thinking and politics" is a new mode of performance evaluation. It will not only focus on Teachers' professional knowledge, but also highlight the comprehensive assessment of teachers' ideological quality. (2) Using the evaluation method of multi-agent participation, teachers, students, leaders and experts objectively and fairly evaluate and supervise the network "curriculum ideological and political" teaching of teachers majoring in digital economy, and formulate relevant reward and punishment mechanisms. Those with good performance can be included in the scope of evaluation; For teachers with poor performance, training and education shall be adopted. We should clearly define the teaching objectives and 
requirements of "Internet plus curriculum thinking", so as to ensure that we provide enough excellent teachers for the professionals in digital economy, effectively promote the implementation of the new mode of "Internet plus curriculum thinking and politics", and ensure the high quality training of professionals in digital economy.

\subsection{Form the Talent Training Mechanism of "Internet Plus Curriculum Thinking Politics"}

Talent is the first resource. To promote the reform of talent training mode of digital economy specialty, we should pay close attention to improving the talent training mechanism. (1) Clarify the training objectives. Colleges and universities should take the demand of the society for digital economy professionals as the guidance, conform to the trend of "Internet plus curriculum thinking and politics", and cultivate high-quality applied talents with professional knowledge of economics and higher ideological awareness. (2) Reform the curriculum system of digital economy. Fully consider the individual differences and learning styles of students majoring in digital economy, and customize the personalized curriculum scheme. Based on the unique vision, theory and method of digital economy specialty, using Internet technology, integrate rich ideological and political elements and ideological and political cases into the curriculum teaching of digital economy specialty, pay attention to the hidden education content, go into the Internet, improve students' Ideological and political consciousness, and create a high-quality ideological and political education atmosphere. Improve the talent training mechanism, train new digital economy professionals with solid professional knowledge of digital economy and good character and quality for the country, and provide the main force for the development of digital economy.

\section{Acknowledgments}

This work is supported by the project of Anhui new liberal arts and new medical research and reform practice project "exploration and practice of digital economy talent training promoted by interdisciplinary integration and diversified cooperation between schools and enterprises under the background of new liberal arts" (Grant No: 2020wyxm002).

\section{References}

[1] Liu Shuhui. Theoretical research on the construction of Internet plus curriculum thinking and politics [J]. Higher education in China, 2017 (Z3), 15-17.

[2] Liu Fangxin. On the teaching reform path of "curriculum ideological and political" in higher vocational colleges from the perspective of student acceptance [J]. Comparative research on cultural innovation, 2019 (35), 155-156.

[3] Yu Cheng, Song Chunhua. (2020). Analysis on the advantages and difficulties of ideological and political courses in colleges and universities under the background of internet [J]. East, West, North and south, 2020 (14), 120-121.

[4] Chen Weizhi. Based on the Internet plus curriculum thinking, the training mode of international economic and trade professionals $[\mathrm{J}]$. Heilongjiang education (theory and practice), $2021(10), 19-20$.

[5] Zhuo Hongming, Jiang Zhongren. "Internet plus" course teaching reform of Ideological and political education in Higher Vocational Education [J]. Journal of Ningbo University of Technology, 2019 (04), 107-111. 